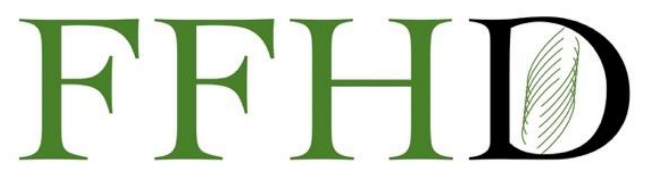

Functional Foods in Health and Disease

\title{
Tuna blood inhibits lipopolysaccharide-induced inflammatory mediators in RAW264.7 macrophages
}

\author{
Wanwimol Klaypradit ${ }^{1,2}$, Mantira Hawangjoo ${ }^{1,2}$, Nujamee Ngasakul ${ }^{1}$, Pennapa \\ Chonpathompikunlert ${ }^{3}$, Maruj Limpawattana ${ }^{4}$, Wanida Sukketsiri ${ }^{5 *}$
}

\begin{abstract}
${ }^{1}$ Department of Fishery Products, Faculty of Fisheries, Kasetsart University, Bangkok, Thailand; ${ }^{2}$ Center for Advanced Studies for Agriculture and Food (CASAF), Kasetsart University Institute for Advanced Studies, Kasetsart University, Bangkok, Thailand; ${ }^{3}$ Expert Centre of Innovative Health Food (InnoFood), Thailand Institute of Scientific and Technological Research (TISTR), Pathum Thani, Thailand; ${ }^{4}$ Department of Food Technology, Faculty of Science, Siam University, Bangkok, Thailand; ${ }^{5}$ Division of Health and Applied Sciences, Faculty of Science, Prince of Songkla University, Songkhla, Thailand
\end{abstract}

*Corresponding author: Wanida Sukketsiri, Ph.D., Division of Health and Applied Sciences, Faculty of Science, Prince of Songkla University, Songkhla 90110, Thailand

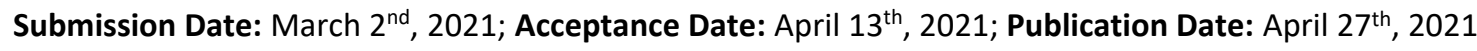

Please cite this article as: Klaypradit W., Hawangjoo M., Ngasakul N., Chonpathompikunlert P., Limpawattana M., Sukketsiri W. Tuna Blood Inhibits Lipopolysaccharide-induced Inflammatory Mediators in RAW264.7 Macrophages. Functional Foods in Health and Disease 2021; 11(4): 201-212. DOI: https://www.doi.org/10.31989/ffhd.v11i4.785

\footnotetext{
ABSTRACT

Background: This study aimed to evaluate the anti-inflammation effects of the freeze-dried tuna whole blood (FTB), and freeze-dried tuna blood cell (FTC) in LPS-induced RAW264.7 cells.

Methods: The RAW264.7 cells were pre-administered with FTB and FTC at different concentrations for $2 \mathrm{~h}$ and then stimulated with lipopolysaccharide (LPS) for $24 \mathrm{~h}$. The production of reactive oxygen species (ROS), nitric oxide (NO), tumor necrosis factor-alpha (TNF- $\alpha$ ), and interleukin-1 beta (IL-1 $\beta$ ) in RAW 264.7 cells were then determined.

Results: The results showed that only FTB remarkably abolished LPS-induced ROS in RAW264.7 cells. FTB and FTC significantly decreased LPS-induced NO which IC 50 values of FTB and FTC after $24 \mathrm{~h}$ were 78.58 and $22.47 \mu \mathrm{g} / \mathrm{mL}$, respectively. TNF- $\alpha$ and IL-1 $\beta$ secretion were abolished by FTB and FTC in LPS-stimulated macrophages which IC 50 values of both FTB and FTC after $24 \mathrm{~h}$ were more than $25 \mu \mathrm{g} / \mathrm{mL}$, respectively. However, the efficacy of FTC against inflammatory mediators was due to cytotoxic effects on RAW 264.7 cells.
} 


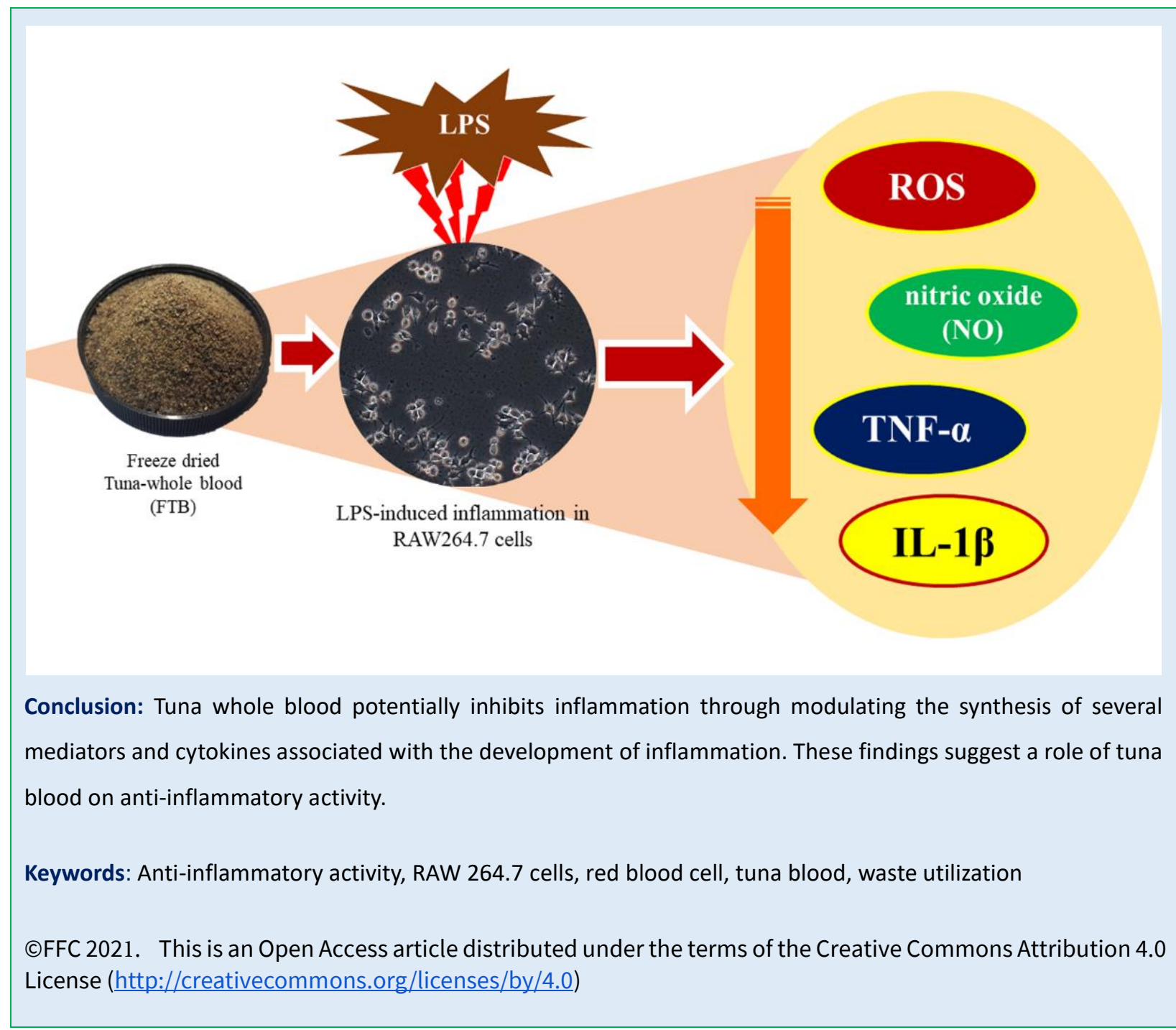

\section{INTRODUCTION}

Canned tuna products have made Thailand one of the most important exporters in the global market. Waste or by-products included heads, bones, skin, viscera, and gills is accounted for $50-55 \%$ of the body weight in tuna production. Most of the by-products have been utilized for more valuable products as fish oil from tuna head [1], calcium from bone [2], or collagen from skin, scale, and bone [3]. However, tuna blood is the only remaining waste that has not been utilized. Normally, the blood is disposed into drainpipes causing a high cost of wastewater treatment for the industry. Recently, the recovery of the tuna blood to create the more valuable products is of great importance for the industry. To date, there has been a growing interest in the investigation of the biological properties of Crocodylus siamensis blood associated with the immune function, anti-bacterial [4], anti-inflammatory, and antioxidant activity [5-7].

The low-grade inflammation and immune stimulation are related with age-associated morbidity and mortality [8]. It has been concerned that the defense mechanism against external or internal stimuli in response to injury may lead to inflammation [9]. Appropriate control of the inflammatory response is crucial to restore the injury and prevent stress and cellular inflammation [10]. The gathering of 
intracellular free radicals causes the secretion of many chemokines and cytokines, for example, interleukin (IL)$1 \beta$, IL-6, tumor necrosis factor (TNF)- $\alpha$, and nitric oxide (NO) negotiate signal transduction pathways including nuclear-kappa $\beta$ factor (NF-k $\beta$ ) as member of the inflammatory reaction [11-13]. Phagocytes, for example, macrophages are the predominant donors to generate oxidative stress and their associated tissue injury [1415]. Oxidation-inflammation has been reported to be correlated with the development of cellular damage in tissue and organ dysfunction, contributing to an increase in morbidity, mortality, and is associated in the aging process [8]. So, the reduction of oxidationinflammation may result in the decrease of cellular dysfunction and organ damage, leading to improve health quality and longevity.

Interestingly, the anti-inflammatory effect of tuna blood on macrophages remains undetermined. Therefore, the present study aimed to examine the antiinflammatory effects of freeze-dried tuna whole blood (FTB) and also freeze-dried tuna blood cell (FTC) against LPS-induced inflammation in murine macrophage RAW264.7 cells.

\section{METHODS}

Materials: Tuna blood was collected from a cannedtuna processing plant in Samut-Sakhon province, Thailand. The blood was packed in polyethylene bags and frozen overnight. The frozen tuna blood was transported to the laboratory within 2 hours, and it was immediately stored at $-20^{\circ} \mathrm{C}$ until use.

Preparation of tuna blood: The frozen tuna blood was thawed at $3-6^{\circ} \mathrm{C}$ for $24 \mathrm{~h}$ prior to the pasteurization process at $63^{\circ} \mathrm{C}$ for $30 \mathrm{~min}$ then it was cooled at $0-4{ }^{\circ} \mathrm{C}$ before used.

Preparation of tuna blood cell: Frozen tuna blood was thawed at $3-6{ }^{\circ} \mathrm{C}$ for $24 \mathrm{~h}$ then it was evaporated using an evaporator $\left(50{ }^{\circ} \mathrm{C}\right.$, pressure at $\left.30 \mathrm{mbar}\right)$ to remove some excess water. After evaporation, the concentrated blood was centrifuged using a refrigerated centrifuge at 2,500 rpm for $30 \mathrm{~min}$ to obtain the sediment (blood cell). The tuna blood cell was further pasteurized at $63^{\circ} \mathrm{C}$ for 30 min then it was cooled at $0-4{ }^{\circ} \mathrm{C}$ before used.

\section{Preparation of dried tuna blood and dried tuna blood} cell: The tuna blood and tuna blood cell were placed in aluminum trays and frozen at $-20{ }^{\circ} \mathrm{C}$ for $24 \mathrm{~h}$ before being dried using a freeze dryer (Labogene, Scanvac coolSafe model, Denmark) for $24 \mathrm{~h}$. The freeze-dried tuna whole blood (FTB), and freeze-dried tuna blood cell (FTC) were obtained after drying.

\section{Determination of mineral contents in FTB and FTC: The} FTB and FTC were determined for iron (Fe), zinc (Zn), phosphorus $(\mathrm{P})$, and magnesium ( $\mathrm{Mg}$ ) according to Poitevin [16].

Cell culture: The murine macrophage RAW264.7 cell line was purchased from American Type Culture Collection (Manassas, VA, USA). The complete DMEM media containing $10 \%$ fetal bovine serum (FBS), $1 \%$ penicillin/streptomycin, and 1\% L-glutamine (Gibco, USA) were used to maintain the RAW264.7 cells in an incubator with $5 \% \mathrm{CO}_{2}$ at $37{ }^{\circ} \mathrm{C}$. RAW264.7 cells were subcultured every 3-4 days. 
Cytotoxicity assay: RAW264.7 macrophages were maintained with the complete DMEM medium in a 96well plate. After cell detachment, FTB, and FTC at the concentration of $0,1,5,10,25,50,75,100$, and 250 $\mu \mathrm{g} / \mathrm{mL}$ were then treated to the cells for $24 \mathrm{~h}$. Colorimetric MTT assay was used to measure the viability of the RAW264.7 cells after treatment with FTB and FTC. A microplate reader (Bio-Tex Instruments, Inc., VT, USA) was used to detect the optical density (OD) of each well at $570 \mathrm{~nm}$.

Reactive oxygen species (ROS) level assay: The $2^{\prime}, 7^{\prime}-$ dichlorofluorescein diacetate (DCFH-DA) (Sigma, St. Louis, MO, USA) oxidation was used for evaluating the intracellular ROS generation in RAW264.7 cells. Briefly, FTB and FTC at the concentration of 5,10 , and $25 \mu \mathrm{g} / \mathrm{mL}$ were pre-treated for $2 \mathrm{~h}$ and subsequently the $1 \mu \mathrm{g} / \mathrm{mL}$ of lipopolysaccharide (LPS) from Escherichia coli 055: B5 (Sigma, St. Louis, MO, USA) was applied to RAW264.7 cells $\left(5 \times 10^{4}\right.$ cells/well) for $24 \mathrm{~h}$. Finally, the DCFH-DA $(50 \mu \mathrm{M})$ was added into each well and incubated in the dark for $1 \mathrm{~h}$. An excitation wavelength of $485 \mathrm{~nm}$ and an emission wavelength of $530 \mathrm{~nm}$ was used to determine DCF fluorescence intensity by a fluorescence microplate reader (Bio-Tex Instruments, Inc., VT, USA).

Nitric oxide (NO) level assay: FTB and FTC at the concentration of 5,10 , and $25 \mu \mathrm{g} / \mathrm{mL}$ and dexamethasone $(1 \mu \mathrm{g} / \mathrm{mL})$, as a positive drug were pretreated for $2 \mathrm{~h}$ and subsequently the $1 \mu \mathrm{g} / \mathrm{mL}$ of LPS was applied into RAW264.7 cells ( $5 \times 10^{4}$ cells/well) for $24 \mathrm{~h}$. Then, one-hundred microliter of media was mixed with one-hundred microliters of Griess reagent. The optical densities of the nitrite-containing samples were detected by a microplate reader (Bio-Tex Instruments, Inc., VT, USA) at $540 \mathrm{~nm}$. A standard curve of sodium nitrite was used to estimate nitrate concentrations in the medium.

TNF- $\alpha$ and IL-16 level assay: FTB and FTC at the concentration of 5,10 , and $25 \mu \mathrm{g} / \mathrm{mL}$ and dexamethasone $(1 \mu \mathrm{g} / \mathrm{mL})$, as a positive drug were pretreated for $2 \mathrm{~h}$ and subsequently the $1 \mu \mathrm{g} / \mathrm{mL}$ of LPS was applied to RAW264.7 cells ( $1 \times 10^{5}$ cells/well) for $24 \mathrm{~h}$. After completion of incubation, enzyme-linked immunosorbent assay (ELISA) (Merck, Darmstadt, Germany) method was used to measure the secretion of TNF- $\alpha$ and IL-1 $\beta$ from RAW264.7 cells cultured medium.

Statistical analysis: Values were expressed as mean \pm standard error of results. For testing the differences of the mean values, ANOVA and Tukey post hoc test were utilized to compare between groups, and statistically significant was accepted at $P<0.05$.

\section{RESULTS AND DISCUSSION}

Mineral contents of FTB and FTC: Table 1 shows the mineral contents found in FTB and FTC. The results indicated that FTC had higher iron, zinc, and magnesium content than that found in FTB. It could be explained that the blood cell containing red blood cells normally contain haemoglobin, which is a rich source of heme iron and zinc [17] whereas the whole blood is composed of albumin, globulin, and fibrinogen and also haemoglobin [18]. Zinc plays a critical role in haemoglobin synthesis and erythropoiesis whereas iron is essential for oxygen transport and storage and many 
other metabolic functions related to immunity, growth,

FTB was similar to the amount found in FTC.

bone strength, muscular activity, and the nervous

system. [19]. However, phosphorus content found in

Table 1. The mineral content of freeze-dried tuna whole blood (FTB) and freeze-dried tuna blood cell (FTC)

\begin{tabular}{|c|c|c|}
\hline \multirow[t]{2}{*}{ Mineral } & \multicolumn{2}{|c|}{ Content (mg/100 g) } \\
\hline & FTB & FTC \\
\hline Iron (Fe) & 102.10 & 252.20 \\
\hline Zinc (Zn) & 16.00 & 31.30 \\
\hline Phosphorus (P) & 106.00 & 107.00 \\
\hline Magnesium & 328.70 & 419.60 \\
\hline
\end{tabular}

Note: the values obtained from 2 replication of measurement

\section{Effects of FTB and FTC on cell viability in RAW264.7}

cells: It is essential to analyze the cytotoxicity of the FTB and FTC on the macrophages to confirm the safety of each sample before using it as a functional food product for human consumption. RAW264.7 murine macrophages were used to study the response of each compound to the immune system, which is comparative to the human body defense system $[13,20]$. MTT cell viability assay was first performed for the cytotoxicity evaluation of FTB and FTC on macrophages. RAW264.7 cells incubated with FTB and FTC $(0-250 \mu \mathrm{g} / \mathrm{mL})$ for 24 h. As shown in Figure 1A, a concentration of 5-250 $\mu \mathrm{g} / \mathrm{mL}$ FTC significantly decreased $(p<0.001)$ the percentage of cell viability of RAW264.7 cells after $24 \mathrm{~h}$ treatment. However, the percentage of cell viability was higher than $80 \%$ after treatment with FTC at the concentration range of $5-25 \mu \mathrm{g} / \mathrm{mL}$. In contrast to FTC, a concentration range of 1-75 $\mu \mathrm{g} / \mathrm{mL}$ FTB did not affect the viability of the RAW264.7 cells while $100-250 \mu \mathrm{g} / \mathrm{mL}$ of FTB significantly decreased $(p<0.001)$ the percentage of cell viability of RAW264.7 cells after $24 \mathrm{~h}$ treatment (Figure 1A). The half-maximal inhibitory concentration $\left(\mathrm{IC}_{50}\right)$ values of FTC and FTB after $24 \mathrm{~h}$ were 71.05 , and $124.83 \mu \mathrm{g} / \mathrm{mL}$, respectively (Figure $1 \mathrm{~B}$ ). Based on our results, FTC showed higher toxicity to the macrophage than FTB with the lower $\mathrm{IC}_{50}$. The presence of higher level of iron in the FTC might contribute to the reduction of the RAW264.7 murine macrophage viability. Normally, the small level of iron is necessary for the formation of the blood cells component and other normal physiologic functions [21]. However, a high concentration of iron can interact with hydrogen peroxide to generate the hydroxyl radical, which can lead to injury to the biomolecules such as lipids, proteins, and DNA [22-23]. Besides, overproduction of iron contributes to the development of cardiovascular disease, for example, ischemic heart disease or atherosclerosis, and also inhibits the role of macrophages against the development of cancer [2425]. 


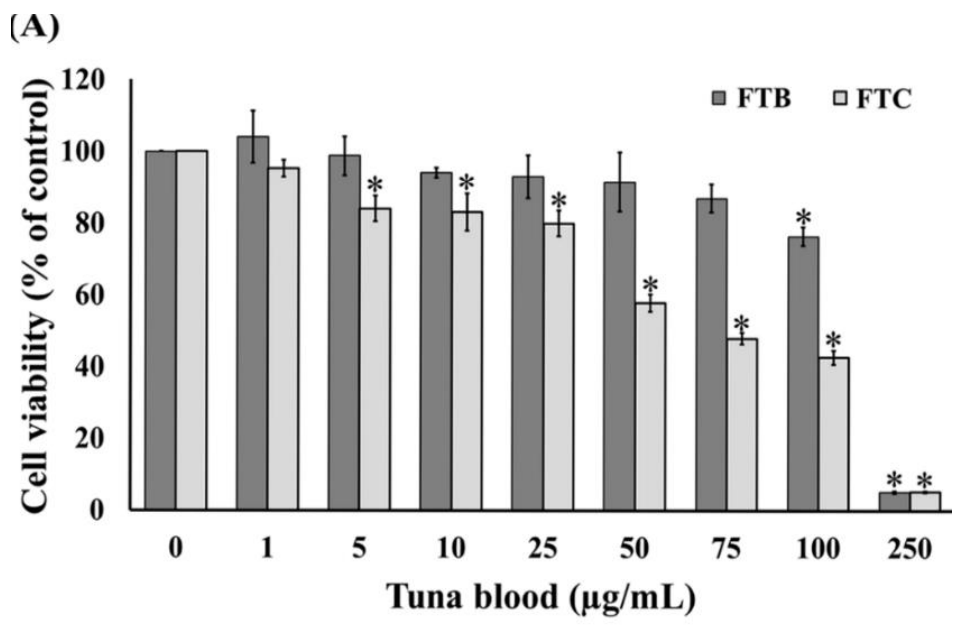

(B)

Tuna Blood

FTB FTC
$\mathrm{IC}_{50}(\mu \mathrm{g} / \mathrm{mL})$

124.83

71.05

Figure 1. (A) Effects of FTB and FTC at different concentrations on cell viability. (B) IC 50 of FTB and FTC. Data are presented as mean \pm S.E.M. for four independent experiments $(n=4) .{ }^{*} p<0.001$ compared to the $0 \mu \mathrm{g} / \mathrm{mL}$.

Effect of FTB and FTC on intracellular reactive oxygen species (ROS) level in RAW264.7 cells: It is well known that oxidative stress is associated with inflammation. Oxidative stress, an increase of intracellular ROS levels, was identified as a powerful inflammatory mediator [26]. It has been known that ROS acts as a valuable mediator for host defense mechanisms and is produced by the phagocytic cells, for example, macrophages in response to microbial or inflammatory stimuli [27]. ROS overproduction causes the provocation of proinflammatory cytokines secretion [28-29]. Moreover, our previous study found that ROS is also a secondary messenger enhanced in LPS-induced inflammatory response $[11,13]$. As shown in Figure 2, LPS caused an increase in the production of intracellular ROS in RAW264.7 macrophages when compared to the untreated control group $(p<0.001)$. The concentration of 10 and $25 \mu \mathrm{g} / \mathrm{mL}$ of FTB significantly diminished $(\mathrm{p}<$ 0.01 ) the LPS-induced ROS production in RAW264.7 macrophages (Figure 2). However, the concentration of 5, 10, and $25 \mu \mathrm{g} / \mathrm{mL}$ of FTC insignificantly downregulated the ROS production in LPS-induced RAW264.7 macrophages (Figure 2) compared to the untreated group. Our results are consistent with those found by Phosri et al. [7], describing the antioxidant activity of blood from the crocodile in fibroblasts MRC5 cells and RAW264.7 macrophages. 


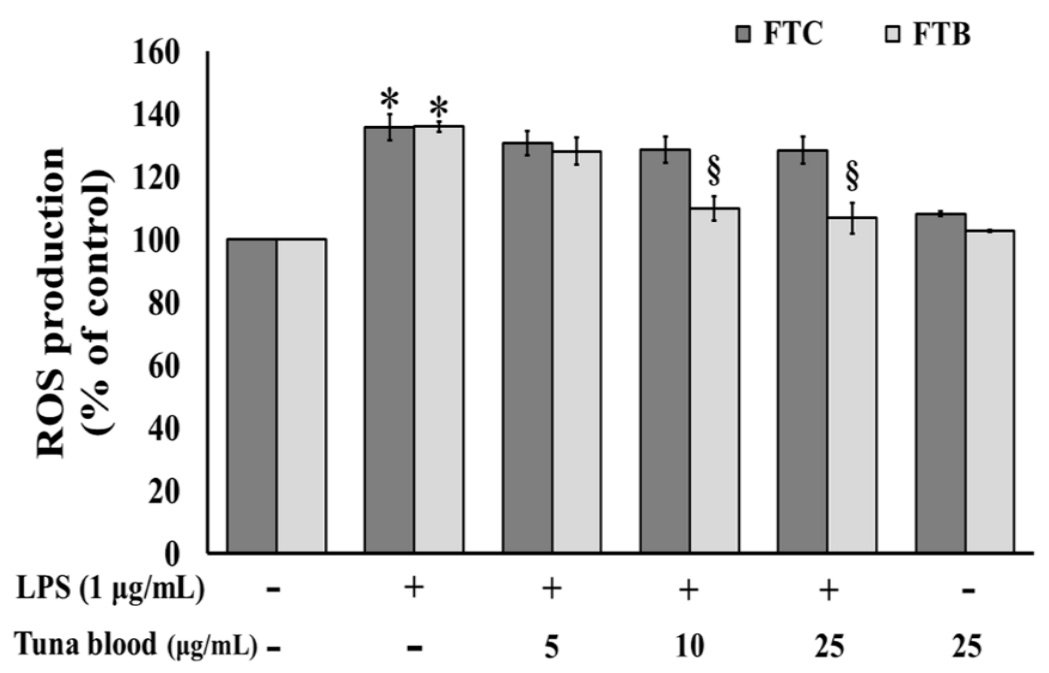

Figure 2. Effect of FTB and FTC on intracellular reactive oxygen species (ROS) level in RAW264.7 cells. Data are presented as mean \pm S.E.M. for four independent experiments $(n=4)$. ${ }^{*} p<0.001$ compared to the normal control group. ${ }^{\S} p<$ 0.01 compared to the LPS group.

Effect of FTB and FTC on nitric oxide (NO) level in RAW264.7 cells: The NO overproduction may contribute to cytotoxic effects through the formation of peroxynitrite and is linked to chronic inflammatory diseases and aging [30]. Subsequently, an inhibiting of NO production could decrease endotoxin-stimulated inflammation. As shown in Figures $3 A$ and $3 C$, the nitrite level in RAW264.7 macrophages cultured medium was significantly enhanced by LPS compared to the untreated control group $(p<0.001)$. FTB at the concentration of 5,10 , and $25 \mu \mathrm{g} / \mathrm{mL}$ significantly decreased $(p<0.01)$ NO level in LPS-induced RAW264.7 macrophages (Figure 3A). The percentage of NO inhibition was upregulated in all concentrations of FTB with increasing FTB concentrations after $24 \mathrm{~h}$ with values of $40.28 \pm 9.32,40.47 \pm 7.26$, and $45.78 \pm 6.05 \%$ after treatment with 5,10 , and $25 \mu \mathrm{g} / \mathrm{mL}$ FTB, respectively (Figure $3 \mathrm{~B}$ ). In addition, the concentration of 5,10 , and $25 \mu \mathrm{g} / \mathrm{mL}$ FTC significantly downregulated ( $p<0.01)$ NO level in LPS-induced RAW264.7 macrophages (Figure 3C) when compared to the untreated group. The percentage of NO inhibition was also significantly increased after 5,10 , and $25 \mu \mathrm{g} / \mathrm{mL}$ of FTC treatment with values of $35.40 \pm 4.91,42.44 \pm 4.03$, and $50.83 \pm 4.52 \%$, respectively (Figure $3 \mathrm{~B}$ ). However, the NO inhibition of FTC might be due to chemically induced cytotoxicity at any dosages that were measured by MTT (Figure 3D). IC 50 values of FTB and FTC after $24 \mathrm{~h}$ were 78.58 and $22.47 \mu \mathrm{g} / \mathrm{mL}$, respectively. Our results are similar to those found by Phosri et al. [7] in fibroblasts cultures exposed to hydrogen peroxide $\left(\mathrm{H}_{2} \mathrm{O}_{2}\right)$ and treated with the blood extract from crocodile blood. Additionally, a positive drug, dexamethasone $(1 \mu \mathrm{g} / \mathrm{mL})$ significantly suppressed the secretion of nitrite in the medium of LPS-induced RAW264.7 macrophages. So far, many researchers have targeted inhibition of the NO secretion, which can be employed for novel anti-inflammatory therapeutics agents $[11,13,31-32]$. 

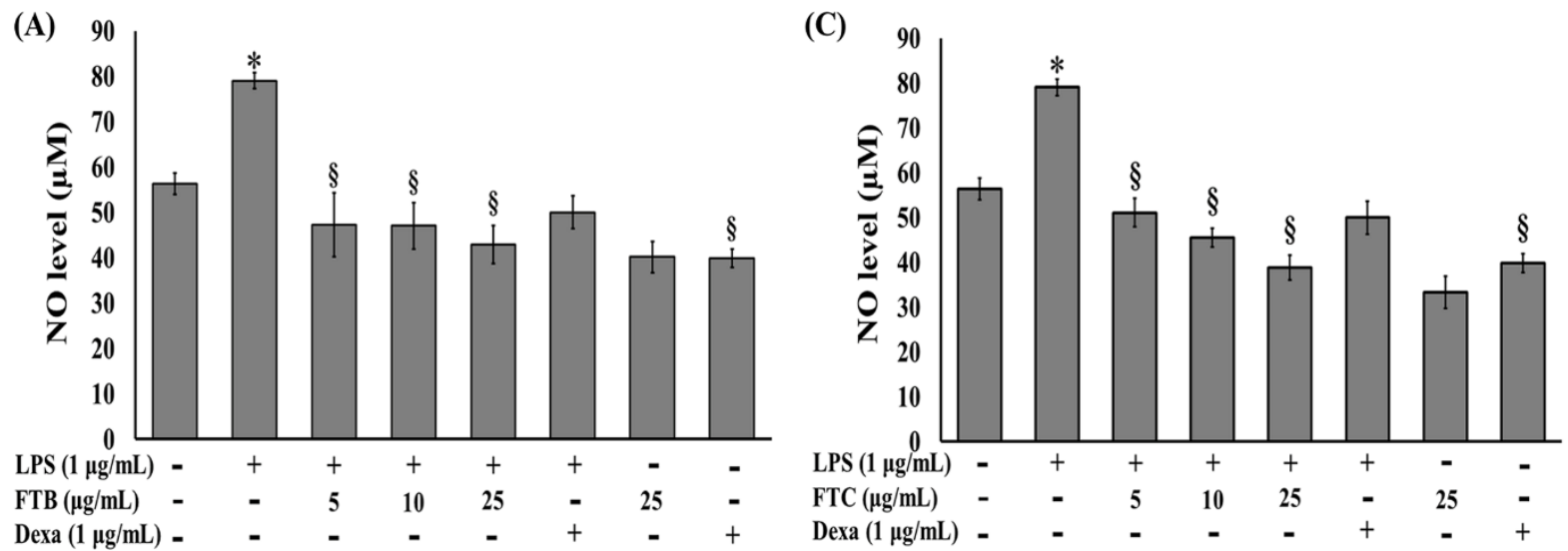

(B)
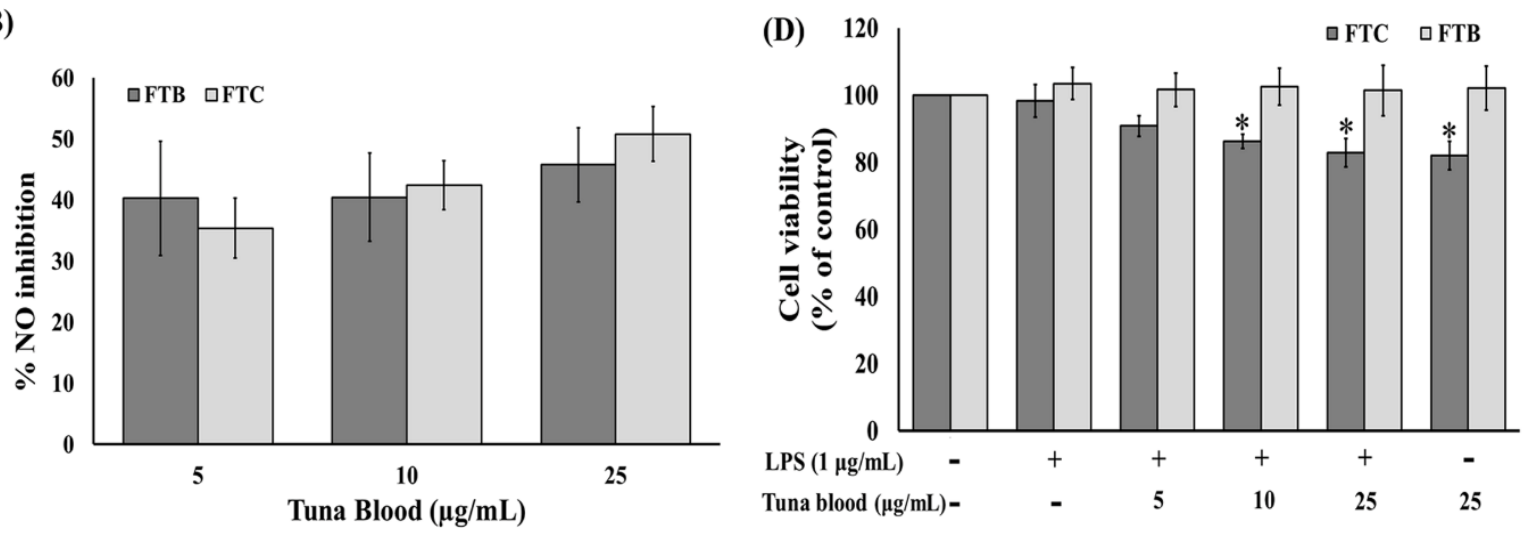

Figure 3. (A) Effect of FTB at different concentrations (5, 10, and $25 \mu \mathrm{g} / \mathrm{mL}$ ) on nitric oxide (NO) level in RAW264.7 cells. (B) \% Inhibitory effects of FTB and FTC cell on NO level in LPS-induced RAW264.7 cells. (C) Effect of FTC at different concentrations $(5,10$, and $25 \mu \mathrm{g} / \mathrm{mL}$ ) on NO level in RAW264.7 cells. (D) Effects of FTB and FTC on cell viability in LPS-induced RAW264.7 cells. Data are presented as mean \pm S.E.M. for four independent experiments $(n=$ 4). ${ }^{*} p<0.001$ compared to the normal control group. ${ }^{\S} \mathrm{p}<0.01$ compared to the LPS group. ${ }^{\#} \mathrm{p}<0.05$ compared to the LPS group.

FTB and FTC inhibits the production of TNF- $\alpha$ and IL-16 level in RAW264.7 cells: Immune cells and macrophages control the inflammatory response and then produce numerous pro-inflammatory mediators such as ROS, NO, TNF- $\alpha$, and IL-1 $\beta$ in reaction to injurious stimuli such as LPS $[13,33]$. The abundance of NO, TNF- $\alpha$ and IL-1 $\beta$ mediators induces the progression of inflammatory disorders [34]. Thus, suppression of NO, TNF- $\alpha$, and IL-1 $\beta$ overproduction is generally used for seeking anti-inflammatory agents $[13,33]$. In this study, LPS significantly enhanced the secretion of TNF- $\alpha$ and IL-1 $\beta$ levels in cultured medium of RAW264.7 macrophages compared to the normal control group ( $p$
$<0.001 ;$ Figure 4 and Figure 5). The concentration of 10 and $25 \mu \mathrm{g} / \mathrm{mL}$ FTB significantly inhibited the release of TNF- $\alpha$ level in the cultured medium of LPS-induced RAW264.7 macrophages ( $p<0.05$ and $p<0.01$; Figure 4A). The percentage of TNF- $\alpha$ inhibition was increased with enhancing FTB concentrations after $24 \mathrm{~h}$ with the values of $11.25 \pm 1.14$, and $24.24 \pm 2.03 \%$ after treatment with 10 and $25 \mu \mathrm{g} / \mathrm{mL}$ FTB, respectively (Figure 4C). While FTC at the concentration of 10 and $25 \mu \mathrm{g} / \mathrm{mL}$ significantly diminished the TNF- $\alpha$ secretion in LPS-induced RAW264.7 macrophages cultured medium ( $p<0.01$; Figure 4B) compared with the untreated group. FTC at 
the concentration of 10 and $25 \mu \mathrm{g} / \mathrm{mL}$ increased the percentage of TNF- $\alpha$ inhibition with the values of 10.79 \pm 2.18 and $21.67 \pm 3.48 \%$, respectively (Figure $4 \mathrm{C}$ ). $I C_{50}$ values of both FTB and FTC after $24 \mathrm{~h}$ were more than $25 \mu \mathrm{g} / \mathrm{mL}$. Additionally, the secretion of IL-1ß into the medium of LPS-induced RAW264.7 macrophages significantly decreased after FTB at all concentrations of treatment $(p<0.05$, and $p<0.01$; Figure $5 A)$. The percentage of IL-1 $\beta$ inhibition was upregulated in all concentration of FTB with increasing FTB concentrations after $24 \mathrm{~h}$ with the values of 26.88 $\pm 2.59,36.77 \pm 1.75$, and $52.30 \pm 1.49 \%$ after treatment with 5,10 , and $25 \mu \mathrm{g} / \mathrm{mL}$ of FTB, respectively (Figure $5 C)$. Even though the IL-1 $\beta$ level in the medium of LPSinduced RAW264.7 macrophages was significantly downregulated after treatment with 10 and $25 \mu \mathrm{g} / \mathrm{mL}$ of FTC ( $<<0.01$; Figure 5B) when compared to the untreated group. The percentage of IL-1 $\beta$ inhibition increased after 10 and $25 \mu \mathrm{g} / \mathrm{mL}$ FTC treatment with the values of $22.20 \pm 4.45$, and $30.83 \pm 5.84 \%$, respectively (Figure $5 \mathrm{C}$ ). However, the TNF- $\alpha$ and IL-1 $\beta$ inhibition of FTC might be due to chemically induced cytotoxicity at any dosages that were measured by MTT (Figure 3D). Our results are consistent with the previous reports on fibroblasts cultures exposed to $\mathrm{H}_{2} \mathrm{O}_{2}$ and treated with the blood extract from crocodile [7] who reported the anti-inflammatory effects through downregulation of TNF- $\alpha$ and IL-1 $\beta$ production. Based on our results, tuna blood downregulates the production of the pro-inflammatory mediators (IL-1 $\beta$ and TNF- $\alpha$ ) that will be helpful for the prevention and treatment of inflammatory-related disorders. However, it remains unclear on the exact pathway that regulates the anti-inflammatory activity of tuna blood in LPS-induced RAW264.7 cells.
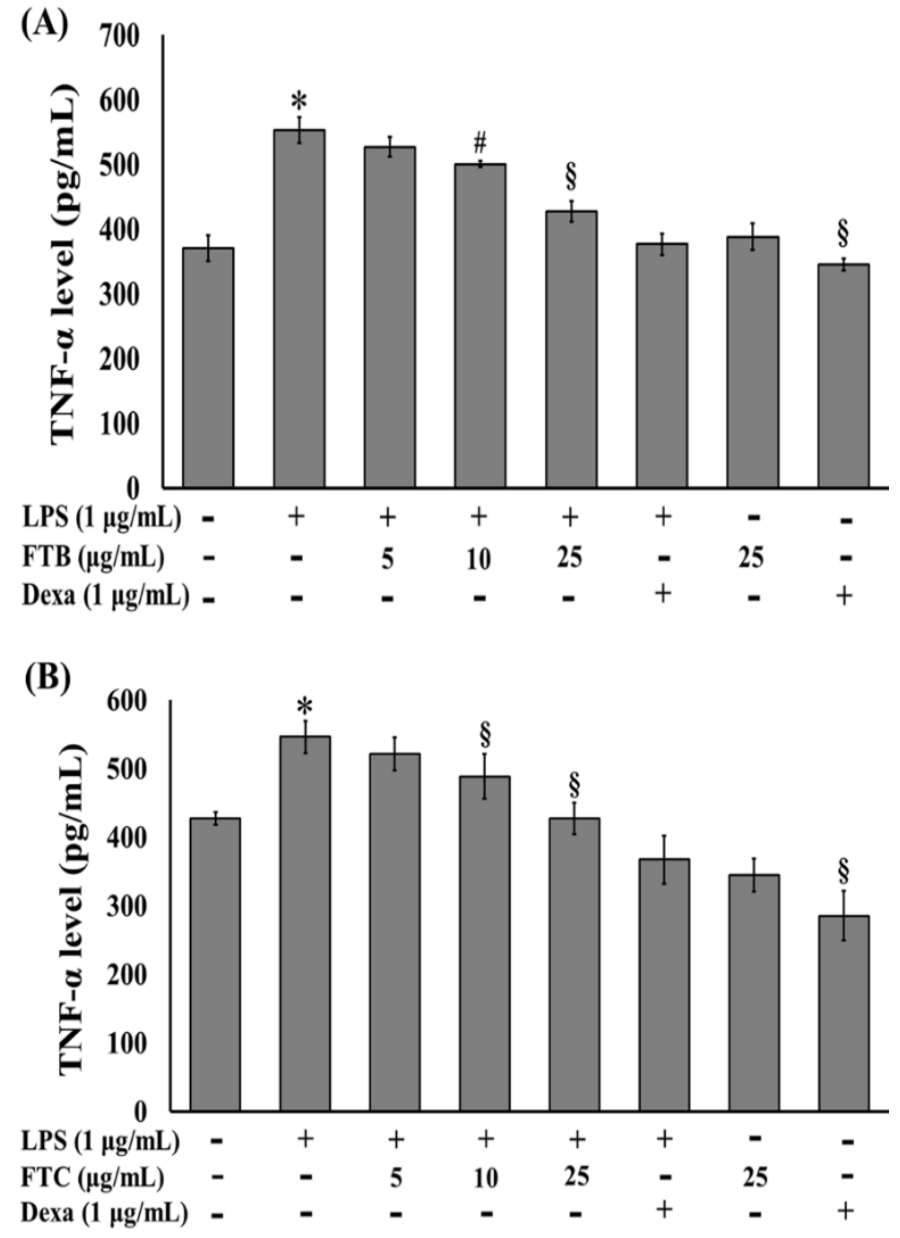

(C)

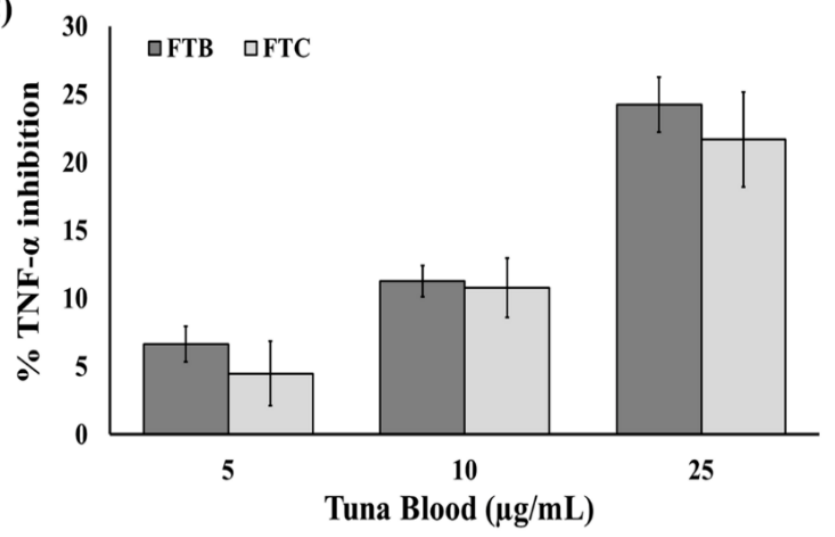

Figure 4. Effect of FTB (A) and FTC (B) at different concentrations $(5,10$, and $25 \mu \mathrm{g} / \mathrm{mL})$ on TNF- $\alpha$ level in RAW264.7 cells. (C) \% inhibitory effects of FTB and FTC on TNF- $\alpha$ level in LPS-induced RAW264.7 cells. Data are presented as mean \pm S.E.M. for four independent experiments $(n=4)$. ${ }^{*} p<0.001$ compared to the normal control group. ${ }^{\S} p<0.01$ compared to the LPS group. ${ }^{\#} p$ $<0.05$ compared to the LPS group. 

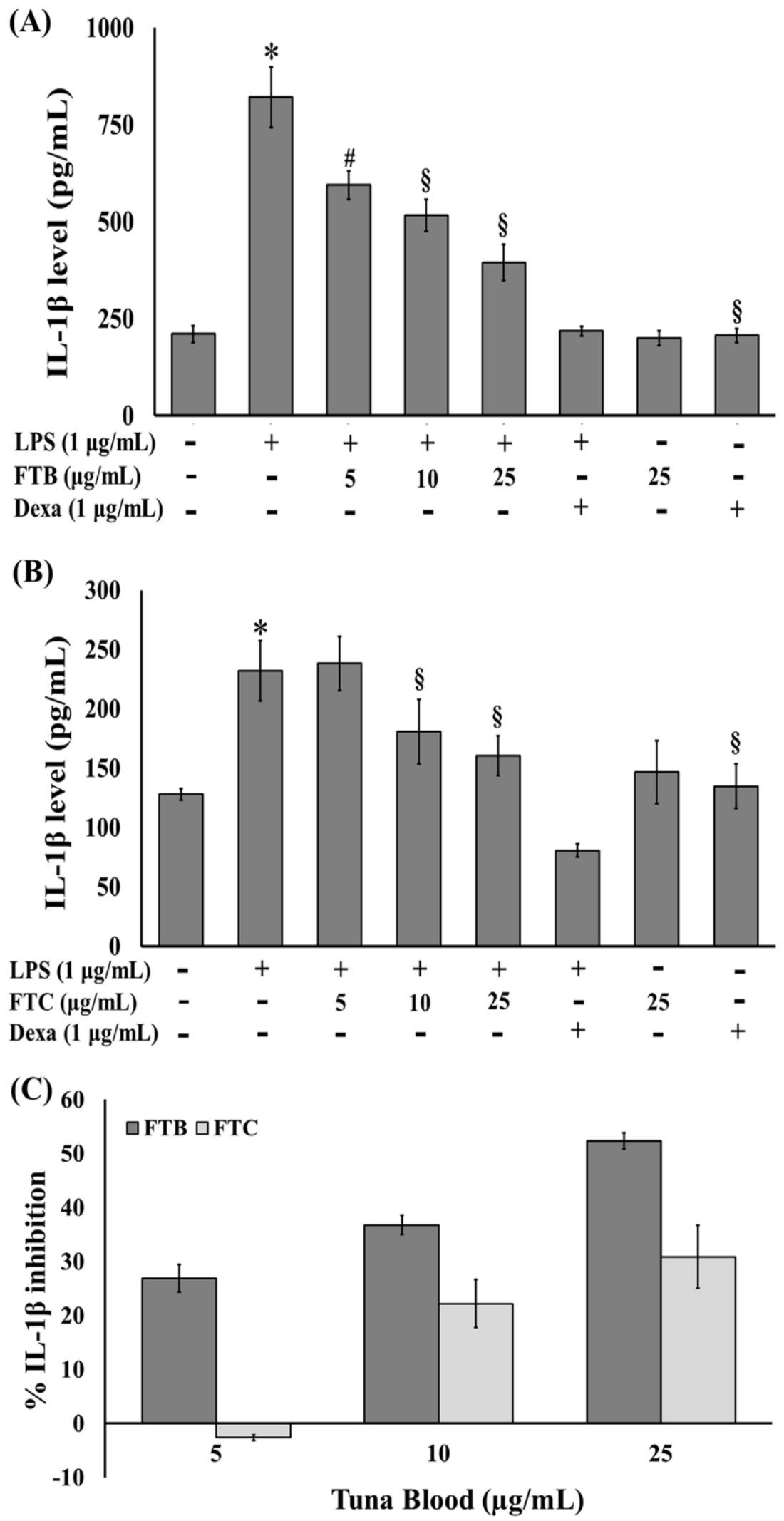

Figure 5. Effect of FTB (A) and FTC (B) at different concentrations $(5,10$, and $25 \mu \mathrm{g} / \mathrm{mL}$ ) on IL-1 $\beta$ in RAW 264.7 cells. (C) \% inhibitory effects of FTB and FTC on IL-1 $\beta$ level in LPS-induced RAW264.7 cells. Data are presented as mean \pm S.E.M. for four independent experiments $(n=4) .{ }^{*} p<0.001$ compared to the normal control group. ${ }^{\S} p<0.01$ compared to the LPS group. $\# p<0.05$ compared to the LPS group. 


\section{CONCLUSION}

Altogether, our data clearly acknowledges that tuna blood exhibits anti-inflammatory properties through its capability to control the generation of ROS, NO, TNF- $\alpha$, and IL-1ß in LPS-induced RAW264.7 cells. However, the mechanism of the anti-inflammatory effect of tuna blood in both in vitro and in vivo needs to further clarify.

List of abbreviations: FTB: freeze-dried tuna whole blood, FTC: freeze-dried tuna blood cell, LPS: lipopolysaccharide, ROS: reactive oxygen species, NO: nitric oxide, TNF- $\alpha$ : tumor necrosis factor-alpha, IL-1 $\beta$ : interleukin-1 beta

Authors' contributions: WK and WS designed the research, conducted the experiments, and prepared the manuscript; $\mathrm{MH}$ and $\mathrm{NN}$ analyzed the data; $\mathrm{PC}$ and $\mathrm{ML}$ prepared the manuscript.

Competing Interests: The authors declare no conflict of interest.

Acknowledgements and Funding: The authors thank Kasetsart University Research and Development Institute for financial support. The authors are thankful for Publication Clinic of Prince of Songkla University for providing assistance in proofreading on the manuscript.

\section{REFERENCES}

1. De Oliveira DASB, Minozzo MG, Licodiedoff S, Waszczynskyj N: Physicochemical and sensory characterization of refined and deodorized tuna (Thunnus albacares) by-product oil obtained by enzymatic hydrolysis. Food Chem 2016, 207:187-194.

2. Benjakul S, Karnjanapratum S: Characteristics and nutritional value of whole wheat cracker fortified with tuna bone bio-calcium powder. Food Chem 2018, 259:181-187.

3. Ahmed R, Haq M, Chun BS: Characterization of marine derived collagen extracted from the by-products of big eye tuna (Thunnus obesus). Int J Biol Macromol 2019, 135:668676.

4. Kommanee J, Preecharram S, Daduang S, Temsiripong Y, Dhiravisit A, Yamada Y, Thammasirirak S: Antibacterial activity of plasma from crocodile (Crocodylus siamensis) against pathogenic bacteria. Ann Clin Microbiol Antimicrob 2012, 11:1-8.

5. Jandaruang J, Siritapetawee J, Thumanu K, Songsiriritthigul C, Krittanai C, Daduang S, Dhiravisit A, Thammasirirak S: The effects of temperature and $\mathrm{pH}$ on secondary structure and antioxidant activity of Crocodylus siamensis hemoglobin. Protein J 2012, 31:43-50.

6. Phosri $\mathrm{P}$, Mahakunakorn $\mathrm{P}$, Lueangsakulthai J, Jangpromma N, Swatsitang P, Daduang S, Dhiravisit A, Thammasirirak S: An investigation of antioxidant and antiinflammatory activities from blood components of crocodile (Crocodylus siamensis). Protein J 2014, 33:484492.

7. Phosri S, Jangpromma N, Patramanon R, Kongyingyoes B, Mahakunakorn P, Klaynongsruang S: Protective effect of crocodile hemoglobin and whole blood against hydrogen peroxide-induced oxidative damage in human lung fibroblasts (MRC-5) and inflammation in mice. Inflammation 2017, 40:205-220.

8. De la Fuente M, Miquel J: An update of the oxidationinflammation theory of aging: the involvement of the immune system in oxi-inflamm-aging. Curr Pharm Des 2009, 15:3003-3026.

9. Mittal M, Siddiqui MR, Tran K, Reddy SP, Malik AB: Reactive oxygen species in inflammation and tissue injury. Antioxid Redox Signal 2014, 20:1126-1167.

10. Lugrin J, Rosenblatt-Velin N, Parapanov R, Liaudet L: The role of oxidative stress during inflammatory processes. Biol Chem 2014, 395:203-230.

11. Moolsap F, Tanasawet S, Tantisira MH, Hutamekalin P, Tipmanee V, Sukketsiri W: Standardized extract of Centella asiatica ECa 233 inhibits lipopolysaccharideinduced cytokine release in skin keratinocytes by suppressing ERK1/2 pathways. Asian Pac J Trop Biomed 2020, 10:273-280.

12. Srivastava $S$, Singh D, Patel S, Singh MR: Role of enzymatic free radical scavengers in management of oxidative stress and autoimmune disorders. Int J Biol Macromol 2017, 101:502-517.

13. Sukketsiri W, Tanasawet S, Moolsap F, Tantisira $\mathrm{MH}$, Hutamekalin P, Tipmanee V: ECa 233 suppresses LPS- 
induced proinflammatory responses in macrophages via suppressing ERK1/2, p38 MAPK and Akt pathways. Biol Pharm Bull 2019, 42:1358-1365.

14. Arango Duque G, Descoteaux A: Macrophage cytokines: involvement in immunity and infectious diseases. Front Immunol 2014, 5:1-12.

15. De la Fuente $M$. Role of neuroimmunomodulation in aging. Neuroimmunomodulation 2008, 15:213-223.

16. Poitevin E. Official methods for the determination of minerals and trace elements in infant formula and milk products: A review. J AOAC Int 2016, 99:42-52.

17. Lynch SA, Mullen AM, O'Neill EE, Garcia CA: Harnessing the potential of blood proteins as functional ingredients: A review of the state of the art in blood processing. Compr Rev Food Sci Food Saf 2017, 16:330-344.

18. Verma AK, Chatli MK, Mehta N, Kumar P: Assessment of physico-chemical, antioxidant and antimicrobial activity of porcine blood protein hydrolysate in pork emulsion stored under aerobic packaging condition at $4 \pm 1{ }^{\circ} \mathrm{C}$. LWT-Food Sci Technol 2018, 88:71-79.

19. Blanco-Rojo R, Vaquero MP: Iron bioavailability from food fortification to precision nutrition. A review. Innov Food Sci Emerg Technol 2019, 51:126-138.

20. Yoon T, Lee DY, Lee AY, Choi G, Choo BK, Kim HK: Antiinflammatory effects of Glehnia littoralis extract in acute and chronic cutaneous inflammation. Immunopharmaco Immunotoxicol 2010, 32:663-670.

21. Collins JF, Prohaska JR, Knutson MD: Metabolic crossroads of iron and copper. Nutr Rev 2010, 68:133-147.

22. Eid R, Arab NTT, Greenwood MT: Iron mediated toxicity and programmed cell death: A review and a reexamination of existing paradigms. Biochim Biophys Acta Mol Cell Res 2017, 1864:399-430.

23. Sohn YS, Mitterstiller AM, Breuer W, Weiss G, Cabantchik ZL: Rescuing iron-overloaded macrophages by conservative relocation of the accumulated metal. $\mathrm{Br} \mathrm{J}$ Pharmacol 2011, 164:406-418.

24. Gujja P, Rosing DR, Tripodi DJ, Shizukuda Y: Iron overload cardiomyopathy: better understanding of an increasing disorder. J Am Coll Cardiol 2010,56:1001-1012.
25. Vinchi F, Muckenthaler MU, Da Silva MC, Balla G, Balla J, Jeney V: Atherogenesis and iron: from epidemiology to cellular level. Front Pharmacol 2014, 5:1-20.

26. Choi JE, Heo SH, Kim MJ, Chung WH: Lack of superoxide dismutase in a rad51 mutant exacerbates genomic instability and oxidative stress-mediated cytotoxicity in Saccharomyces cerevisiae. Free Radic Biol Med 2018, 129:97-106.

27. Leavy O: A link between autoimmunity and cancer?. Nat Rev Immunol 2014, 14: 67

28. Bryan N, Ahswin H, Smart N, Bayon Y, Wohlert S, Hunt JA: Reactive oxygen species (ROS)-a family of fate deciding molecules pivotal in constructive inflammation and wound healing. Eur Cell Mater 2012, 24:249-265.

29. Schieber M, Chandel NS: ROS function in redox signaling and oxidative stress. Curr Biol 2014, 24:R453-R462.

30. Wu D, Hu Q, Zhu D: An update on hydrogen sulfide and nitric oxide interactions in the cardiovascular system. Oxid Med Cell Longev 2018, 1:1-16.

31. Wei J, Zhang X, Bi Y, Miao R, Zhang Z, Su H: Antiinflammatory effects of cumin essential oil by blocking JNK, ERK, and NF-KB signaling pathways in LPS-stimulated RAW264.7 cells. Evid Based Complement Alternat Med 2015, 2015:474509.

32. Zhou Y, Wang J, Yang W, Qi X, Lan L, Luo L, Yin Z: Bergapten prevents lipopolysaccharide-induced inflammation in RAW264.7 cells through suppressing JAK/STAT activation and ROS production and increases the survival rate of mice after LPS challenge. Int Immunopharmacol 2017, 48:159-168.

33. Kim HN, Kim JD, Park SB, Son HJ, Park GH, Eo HJ, Kim HS, Jeong JB: Anti-inflammatory activity of the extracts from Rodgersia podophylla leaves through activation of Nrf2/HO-1 pathway, and inhibition of NF-KB and MAPKs pathway in mouse macrophage cells. Inflamm Res 2020, 69:233-244.

34. Zou J, Guo P, Lv N, Huang D: Lipopolysaccharide-induced tumor necrosis factor- $\alpha$ factor enhances inflammation and is associated with cancer. Mol Med Rep 2015, 12:6399-6404 